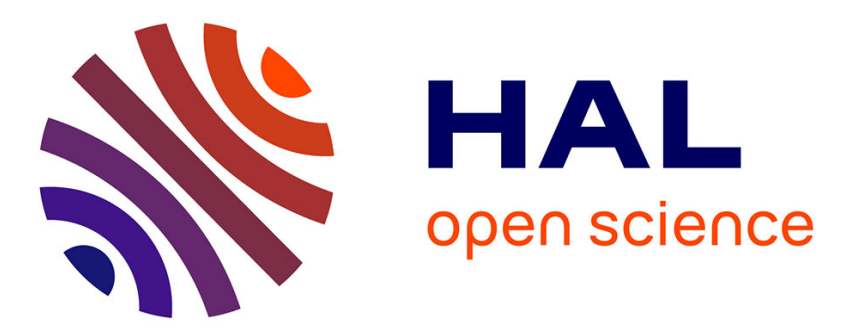

\title{
Are Time and Money Equally Substitutable for All Commodity Groups in the Household's Domestic Production?
}

\author{
Carla Canelas, François Gardes, Philip Merrigan, Silvia Salazar
}

\section{To cite this version:}

Carla Canelas, François Gardes, Philip Merrigan, Silvia Salazar. Are Time and Money Equally Substitutable for All Commodity Groups in the Household's Domestic Production?. 2014. hal-01112620

\section{HAL Id: hal-01112620 \\ https://hal-paris1.archives-ouvertes.fr/hal-01112620}

Submitted on 3 Feb 2015

HAL is a multi-disciplinary open access archive for the deposit and dissemination of scientific research documents, whether they are published or not. The documents may come from teaching and research institutions in France or abroad, or from public or private research centers.
L'archive ouverte pluridisciplinaire HAL, est destinée au dépôt et à la diffusion de documents scientifiques de niveau recherche, publiés ou non, émanant des établissements d'enseignement et de recherche français ou étrangers, des laboratoires publics ou privés. 


\section{Documents de Travail du Centre d'Economie de la Sorbonne}

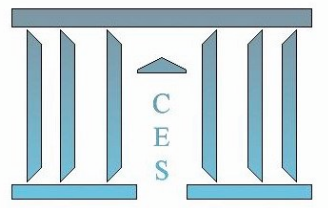

Are Time and Money Equally Substitutable for

All Commodity Groups in the Household's Domestic Production?

Carla CANelas, François GARDES, Philip MERRIGAN, Silvia SALAZAR

2014.71

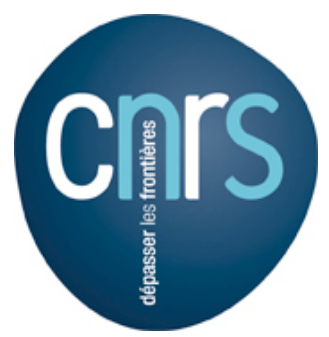




\title{
Are Time and Money Equally Substitutable for All Commodity Groups in the Household's Domestic Production?
}

\author{
Carla Canelas*† \\ François Gardes* \\ Silvia Salazar* \\ September 18, 2014
}

Philip Merrigan

\begin{abstract}
This article uses household data to measure the substitutability between time and money for eight commodity groups and different countries. The elasticities estimated using the household's market wage and an estimated opportunity cost of time are positive, indicating substitutability, and much larger for all goods compared to food. The estimates with the wage rate are, in general, smaller than those obtained using the opportunity cost of time.
\end{abstract}

Keywords: Elasticity of substitution, time use, statistical matching.

JEL Classification: D12, D13, D24

\section{Introduction}

The article adopts Becker's domestic production framework to measure the substitutability between time and monetary expenditures in the production of household goods. Hamermesh's (2008) elasticity estimates with American data range between 0.2 and 0.3 for the case of food, showing that increasing the value of time tends to increase

*Paris School of Economics, Université Paris 1, Centre d'Economie de la Sorbonne, 106-112 Bd de 1'Hôpital, 75013 Paris, France. e-mail addresses: carla.canelas@psemail.eu, gardes@univ-paris1.fr, silvia.salazar@psemail.eu. Tel: +33 (0)1 44078100.

Corresponding author.

†Université du Quebec à Montréal, CIRPÉE, C.P. 8888, Succursale Centre-Ville, Montréal (Québec) H3C 3P8. e-mail address: merrigan.philip@uqam.ca. Tel: +514 987-3000. 
the monetary expenditures relatively to time spent on the domestic production of meals. This confirms the basic intuition that the necessary inputs for the production of meals are rather complementary than substitutes. But what can one expect for other types of commodities? Do leisure and necessity goods follow the same pattern? Moreover, is the market wage a good proxy of the opportunity cost of time?

In this article, the elasticity of substitution is estimated for all types of commodities, for two developed countries, France and Canada, where the opportunity cost of time is closer to the market wage, and two Latin American countries where the opportunity cost is closer to the minimum wage.

\section{Methodology}

We estimate the elasticity of substitution for different goods following the method of Hamermesh (2008). Assuming the household production function for commodity $i$ is CES, the relative demand function can be written as:

$$
\ln \left(\frac{m_{h, i}}{t_{h, i}}\right)=\alpha_{i}+\sigma_{i} \ln \left(w_{h}\right)+\delta_{i} Z_{h}+\epsilon_{h, i}
$$

with $\sigma_{i}$ the value of the elasticity of substitution between goods and time for commodity $i, m_{h, i}$ the monetary expenditure on good $i, t_{h, i}$ time in hours spent on activity $i, w_{h}$ the wage of the household defined as the sum of the wage of the household head and companion, and $Z_{h}$ a vector of standard socio-economic characteristics.

Two methods are used to value the time spent on domestic activities. First, this value is simply the household hourly market wage which is adjusted for income taxes. In the second method, the opportunity cost of time is estimated as in Gardes (2014) 1 .

Contrary to Hamermesh (2008), we estimate the elasticity of substitution for different groups of consumption goods and by educational attainment.

\section{Datasets}

\subsection{National surveys}

For Canada, we use the Survey of Household Spending (SHS) of 1998 which contains annual household expenditures. Because this dataset does not include any information

\footnotetext{
${ }^{1} \mathrm{~A}$ model incorporating the domestic production function in a direct utility depending on the level of home production of final goods leads to first-order conditions corresponding to the substitution between time and money for each final good. These FOC allow the estimation of all the parameters of these functions and finally of the opportunity cost of time.
} 
on time use, we use the General Social Survey (GSS) of 1998 on time use to impute time in the SHS. Because for a large number of households in the SHS it is difficult to know the exact number of individuals in the household as well as the number of children of different ages, we extract households for which we are certain to have the correct number of individuals and age of children. We therefore select married couples without children or with one child less than 14.

The Ecuadorian dataset is composed of two matched surveys: The National Survey of Employment and Unemployment (ENEMDU) 2007 and the Family Expenditure Survey of 2006. The former provides information on time expenditure while the latter reports family monetary expenditures. As in most developing countries, the sampling units are constituted not only of nuclear families but, in large part, of extended families. In order to take into account the income pooling hypothesis, we reduce our sample to couples without children or with one child less than 16.

In the case of France, we use a dataset which combines two surveys: the Family Expenditure Survey (BDF) 2001 which provides information on household expenditures for different goods, and the Family Time Budget (BDT) 1999 which provides detailed time use information for each adult of the household and is used to impute time use in the BDF.

The main data source for Guatemala is the National Survey of Life Conditions (ENCOVI) 2000. This survey combines both monetary and time expenditures, which allows a comparison of the results with the other matched surveys where time use is imputed in the expenditure surveys. As for the case of Ecuador, we work with a reduced sample.

\subsection{Statistical Matching}

We define 9 types of activities compatible with the available data in both Time-Use and expenditure surveys: eating, housing, clothing, transport, education, health, personal care, leisure, and miscellaneous expenditures. The statistical matching between the surveys was done by a regression of the time use for each activity on a common set of socio-economic characteristics of households which are present in both surveys. The estimated coefficients are used to predict time use for each household in the Expenditure surveys.

Since both individuals of the couple are not always observed with earnings, we estimate the labor market wages of those individuals who do not work by the Heckman two step procedure. Variances have to be corrected when predicted variables are used in the estimation. We take care of this by bootstrapping the standard errors. 


\section{Results}

Table 1 shows the estimates of the elasticity of substitution for the four countries under study. Overall, the estimated elasticities are positive and significant. Necessity goods such as food and housing have the lowest elasticity of substitution? This result is similar to the Hamermesh (2008), Chin (2008), and Baral et al. (2011) estimates for food which range from 0.22 to 0.56 . This confirms the existing complementary between time and money for these activities. Inputs of necessity goods are rather complementary since a minimum amount of money and personal time are necessary to produce them and one input cannot be substituted for the other. For instance, the amount of money allocated to buy food, up to a given level, cannot be replaced by time. On the other side, we all need time to eat, and we cannot pay someone else to do it for us ${ }^{3}$.

Table 1: Elasticity of Substitution: Whole Sample

\begin{tabular}{|c|c|c|c|c|c|c|c|c|}
\hline Commodity Groups & Canada (W) & Canada (OC) & Ecuador $(W)$ & Ecuador (OC) & France (W) & France (OC) & Guatemala (W) & Guatemala(OC) \\
\hline \multirow[t]{2}{*}{ Food } & 0.216 & 0.086 & 0.158 & 0.345 & 0.366 & 0.415 & 0.347 & 0.336 \\
\hline & $(0.020)$ & $(0.014)$ & (0.009) & $(0.006)$ & $(0.021)$ & $(0.032)$ & $(0.075)$ & $(0.049)$ \\
\hline \multirow[t]{2}{*}{ Housing } & -0.044 & 0.062 & 0.339 & 0.682 & 0.521 & 0.849 & 0.225 & 0.231 \\
\hline & $(0.014)$ & $(0.009)$ & $(0.015)$ & $(0.010)$ & $(0.023)$ & $(0.034)$ & (0.066) & $(0.052)$ \\
\hline \multirow[t]{2}{*}{ Transport } & 0.461 & 0.382 & 0.432 & 0.547 & 0.399 & 0.287 & 0.323 & 0.531 \\
\hline & $(0.045)$ & $(0.030)$ & (0.024) & $(0.019)$ & $(0.021)$ & $(0.032)$ & $(0.165)$ & $(0.131)$ \\
\hline \multirow[t]{2}{*}{ Clothing } & 0.436 & 0.056 & 0.428 & 0.894 & 1.345 & 1.038 & 0.360 & 0.483 \\
\hline & $(0.038)$ & $(0.026)$ & $(0.023)$ & $(0.017)$ & $(0.051)$ & $(0.067)$ & $(0.101)$ & $(0.089)$ \\
\hline \multirow[t]{2}{*}{ Personal Care } & 0.310 & -0.065 & 0.316 & 0.623 & - & - & 0.516 & 0.547 \\
\hline & (0.033) & $(0.023)$ & (0.015) & $(0.010)$ & & & $(0.102)$ & $(0.071)$ \\
\hline \multirow[t]{2}{*}{ Education } & - & - & 0.241 & 0.564 & - & - & 0.523 & 1.016 \\
\hline & - & - & $(0.027)$ & $(0.021)$ & & & $(0.222)$ & $(0.194)$ \\
\hline \multirow[t]{2}{*}{ Health } & - & - & 0.295 & 0.597 & - & - & 0.674 & 0.540 \\
\hline & - & - & $(0.027)$ & $(0.023)$ & & & $(0.258)$ & $(0.159)$ \\
\hline \multirow[t]{2}{*}{ Leisure } & 0.654 & 0.125 & 0.389 & 1.358 & 0.958 & 1.272 & 0.710 & 1.443 \\
\hline & (0.046) & $(0.032)$ & $(0.252)$ & (0.018) & $(0.032)$ & $(0.047)$ & (0.149) & $(0.195)$ \\
\hline \multirow[t]{2}{*}{ Others } & 0.820 & -1.020 & 0.640 & 0.933 & 0.558 & 0.651 & - & - \\
\hline & $(0.055)$ & $(0.039)$ & $(0.033)$ & $(0.029)$ & $(0.024)$ & $(0.037)$ & - & - \\
\hline \multirow[t]{2}{*}{ All but food } & 0.362 & 0.219 & 0.353 & 1.131 & 0.512 & 0.584 & 0.501 & 0.759 \\
\hline & $(0.020)$ & $(0.014)$ & $(0.019)$ & $(0.005)$ & $(0.015)$ & $(0.023)$ & $(0.140)$ & $(0.168)$ \\
\hline \multirow[t]{2}{*}{ Food* } & 0.216 & 0.086 & 0.115 & 0.506 & 0.281 & 0.276 & 0.304 & 0.451 \\
\hline & $(0.020)$ & $(0.014)$ & $(0.013)$ & $(0.013)$ & $(0.021)$ & $(0.032)$ & $(0.151)$ & $(0.197)$ \\
\hline
\end{tabular}

In general, leisure has the highest elasticity of substitution in all countries. Since there are multiple activities within this commodity and they can generally be either time or money intensive, it is easy to move from one activity to the other without facing any monetary constraint. For example, one can decide to read rather than going to the theater, in which case, one moves from a money intensive activity to a time intensive one, leading to an important substitution between time and money within the activity.

\footnotetext{
${ }^{2}$ See Canelas et al. (2014) for results concerning demand elasticities of these goods.

${ }^{3}$ Indeed, Baral et al. (2011) using American data show that the elasticity of substitution for food is underestimated when time for food includes time for consumption in addition to time for production.
} 
On the contrary, time constraints are important, especially for commodities like personal care, where an exchange between time and monetary inputs is limited. This is reflected by the low coefficient of the elasticity of substitution in Canada and Ecuador. Finally, monetary constraints seem to be the largest burden for most households, which explains that it is for the necessity and money intensive goods that the substitution between time and money is smaller.

The estimates obtained with the opportunity cost of time as explanatory variable are larger for almost all commodity groups in all countries. The results are rather coherent from one country to another except for Canada where elasticities are in general lower when estimated with the opportunity cost 4 . Importantly, the ranking of commodities remains the same, even though the scale of the estimates is rather different for certain goods, in particular leisure. These similarities are remarkable given the important differences in the standard of living between the countries. For instance, in Ecuador, the estimated opportunity cost is in average about $60 \%$ of the minimum wage, which equals the average market wage; while in Guatemala, the opportunity cost is practically the minimum wage, which in turn is 3 times lower than the average market wage.

Overall, the estimates with the opportunity cost are more volatile than those computed with the market wage suggesting that regressing on the wage tends to underestimate the differences between the elasticities.

Table 2 shows the estimates of the elasticity of substitution by educational attainment for Ecuador and Guatemala which have similar patterns of education. For almost all commodities, the elasticity of substitution increases with education. Indeed, in both countries, income level proxied by educational attainment is an important determinant of the magnitude of the elasticity, the higher the education level, the larger the substitution between time and money. This can be attributed to the monetary constraint burdening low income households. This is another hidden constraint imposed to poor households, which has a negative effect on well-being.

Table 2: Elasticity of Substitution: by Education Level

\begin{tabular}{lcccc|cccc}
\hline \multirow{2}{*}{ Commodity Groups } & \multicolumn{4}{c|}{ Ecuador } & \multicolumn{4}{c}{ Guatemala } \\
\cline { 2 - 9 } & WS & Primary & Secondary & Tertiary & WS & Primary & Secondary & Tertiary \\
\hline Food & 0.158 & 0.128 & 0.103 & 0.083 & 0.347 & 0.427 & 0.368 & 0.376 \\
Housing & 0.339 & 0.114 & 0.222 & 0.411 & 0.225 & 0.259 & 0.100 & 0.291 \\
Transport & 0.432 & 0.164 & 0.352 & 0.447 & 0.323 & 0.334 & 0.236 & 0.450 \\
Clothing & 0.428 & 0.152 & 0.391 & 0.422 & 0.360 & 0.269 & 0.706 & 0.193 \\
Personal Care & 0.316 & 0.147 & 0.252 & 0.278 & 0.516 & 0.585 & 0.477 & 0.164 \\
Health & 0.295 & 0.059 & 0.232 & 0.270 & 0.674 & 0.564 & 1.058 & 2.447 \\
Leisure & 0.389 & 0.219 & 0.234 & 0.330 & 0.710 & 0.555 & 0.833 & 0.887 \\
Others & 0.640 & 0.259 & 0.488 & 0.687 & - & - & - & - \\
\hline
\end{tabular}

\footnotetext{
${ }^{4}$ Grouping all other consumptions but food in Canada furnishes the usual order between the elasticity on wage and opportunity cost, although the later remains smaller than expected.
} 


\section{Conclusion}

The results confirm and generalize those obtained in the literature. They are quite similar for the four countries indicating the existing complementarity between inputs of necessity goods, a higher elasticity of substitution for higher educated households, and a higher elasticity on the opportunity cost of time rather than the market wage.

\section{Acknowledgments}

Special thanks are due to Julien Boelaert and Christophe Starzec for treatment of the Canadian and French datasets and Daniel Hamermesh for insightful comments. A grant from ANR MALDI program is acknowledged.

\section{References}

Baral, R., Davis, G., and You, W. (2011). Consumption Time in Household Production: Implications for the Goods-Time Elasticity of Substitution. Economics Letters, 112(2):138-140.

Canelas, C., Gardes, F., and Salazar, S. (2014). Price and Income Elasticities in LAC Countries: The Importance of Domestic Production. Documents de travail du Centre d'Economie de la Sorbonne 14038.

Chin, Y.-M. (2008). A Household Production Model of Demand for Childcare and Meals: Theory and Evidence from the Philippines. Review of Economics of the Household, 6(1):47-64.

Gardes, F. (2014). Full Price Elasticities and the Value of Time: A Tribute to the Beckerian Model of the Allocation of Time. Documents de travail du Centre d'Economie de la Sorbonne 14014.

Hamermesh, D. S. (2008). Direct Estimates of Household Production. Economics Letters, 98(1):31-34. 